\title{
Trends in freshwater microcrustaceans studies in Brazil between 1990 and 2014
}

\author{
W. M. Silva ${ }^{a *}$ and G. Perbiche-Neves ${ }^{b}$ \\ a'Laboratório de Ecologia, Universidade Federal de Mato Grosso do Sul - UFMS, Campus Pantanal, \\ Av. Rio Branco, 1270, CEP 70304-902, Corumbá, MS, Brazil \\ ${ }^{b}$ Centro de Ciências da Natureza, Universidade Federal de São Carlos - UFSCar, Campus Lagoa do Sino Buri, \\ SP, Brazil \\ *e-mail:wmsilvax@ig.com.br
}

Received: October 29, 2015 - Accepted: May 13, 2016 - Distributed: August 31, 2017

(With 2 figures)

\begin{abstract}
This study presents a review of scientiometric data about freshwater microcrustaceans (Copepoda, Ostracoda, Branchiopoda: Cladocera, Anostraca, Notostraca and Conchostraca) in Brazil from 1990-2014. This review is based on 179 papers published across four databases, using the following keywords in the search: microcrustaceans, Copepoda, Cyclopoida, Calanoida, Harpacticoida, Ergasilidae, Daphniidae, Moinidae, Cladocera, Ostracoda, Conchostraca, zooplankton, reservoir, river, ponds, reservoirs, wetlands, caves, lakes, limnology, ecology, aquatic, taxonomy, systematics, morphology and biogeography. No studies were identified that addressed freshwater microcrustaceans in four (Amapá, Roraima, Alagoas and Espírito Santo) of the 27 Brazilian Federative States. Forty-five percent of the included studies were concentrated within three of the most populous states (São Paulo, Minas Gerais and Paraná), which also have a long tradition of limnological study. The included studies mostly addressed reservoirs for hydropower generation (22\%), multiple environments (22\%), rivers (14\%) and small artificial reservoirs (11\%). Pools, ponds, small lakes, wetlands and phytothelma were not widely studied. Cladocera (48\%) and Copepoda (48\%) were the most studied groups. No studies were identified that addressed Notostraca, Anostraca or Conchostraca. The sharp increase in the number of published freshwater studies after 2000 is likely a result of increased internet facilities and the implementation of the Scielo platform. Ecology was most frequently the study focus $(\sim 50 \%)$, followed by taxonomy. Three journals (two Brazilian and one international) accounted for the publication of $44 \%$ of the Brazilian studies on microcrustaceans. We expect the frequency of studies employing newer technologies to increase in the coming years. Based on our findings, we propose that future studies should focus on the least well-studied states and should integrate biogeography and systematic approaches. Further data on the fauna within environmental sub-types in Brazil is required.
\end{abstract}

Keywords: Cladocera, Copepoda, Ostracoda, Conchostraca, study approaches.

\section{Tendências nos estudos de microcrustáceos de água doce no Brasil entre 1990 e 2014}

\section{Resumo}

Esse estudo apresenta uma revisão cienciométrica para trabalhos com microcrustáceos de água doce (Copepoda, Ostracoda, Branchiopoda: Cladocera, Anostraca Notostraca e Conchostraca) no Brasil entre 1990-2014. Essa revisão foi baseada em 179 artigos científicos encontrados em quatro bases de dados, usando as seguintes palavras-chave: Microcrustáceos, Copepoda, Cyclopoida, Calanoida, Harpacticoida, Ergasilidae, Chydoridae, Daphniidae, Moinidae, Cladocera, Ostracoda, Conchostraca, Zooplankton, reservatório, rio, lagoas, áreas inundáveis, cavernas, lagos, limnologia, ecologia, aquático, taxonomia, sistemática, morfologia e biogeografia. Não foram encontrados estudos para microcrustáceos de água doce em quatro (Amapá, Roraima, Alagoas e Espírito Santo) dos 27 Estados da Federação Brasileira. Quarenta e cinco por cento dos estudos foram concentrados em três dos estados mais populosos (São Paulo, Minas Gerais e Paraná), os quais têm longa tradição em estudos limnológicos. A maioria dos estudos analisou reservatórios de hidrelétricas (22\%), ambientes múltiplos (22\%), rios (14\%) e pequenos reservatórios artificiais (11\%). Ambientes tais como, pequenos lagos, poças, lagoas, brejos e fitotelmatas não foram muito estudados. Cladocera (48\%) e Copepoda (48\%) foram os grupos mais estudados. Não foram encontrados trabalhos que analisaram Notostraca, Anostraca ou Conchostraca. O salto no número de estudos publicados depois do ano 2000 parece ser resultado do aumento das facilidades da internet e criação da plataforma Scielo. Ecologia foi a área mais focada nos estudos ( $~ 50 \%)$, seguida pela taxonomia. Três revistas (duas brasileiras e uma internacional) contêm $44 \%$ dos artigos publicados sobre 
microcrustáceos no Brasil. Espera-se que a frequência de estudos utilizando novas tecnologias aumente nos próximos anos. Baseado nos nossos resultados, propõe-se que trabalhos futuros devam focar os estados menos estudados e integrem abordagens biogeográficas e sistemáticas. Mais dados sobre a fauna de microcrustáceos dentro dos tipos de ambiente menos estudados no Brasil também são necessários.

Palavras-chave: Cladocera, Copepoda, Ostracoda, Conchostraca, abordagens de estudos.

\section{Introduction}

Microcrustaceans are efficient in transferring energy and biomass between producers and consumers and are useful for monitoring water quality (Landa et al., 2007) and climate changes (Richardson, 2008; Vadadi-Fülöp et al., 2012). Copepoda, Ostracoda and Branchiopoda (Cladocera (Diplostrasca), Conchostraca, Notostraca and Anostraca) are the most abundant among microcrustacean groups frequently found in freshwater/inland systems such as rivers, lakes, reservoirs, phytothelmas, and wetlands (Thorp and Covich, 2001)

Efforts to increase the awareness of biodiversity in freshwater have been made, such as those published by Hydrobiologia (vol. 595) where some microcrustacean groups were considered. In this issue, general information about these organisms can be found for cladocerans (Forró et al., 2008), copepods (Boxshall and Defaye, 2008), ostracods (Martens et al., 2008) and large branchiopods (Brendonck et al., 2008). In Brazil some compilations concerning freshwater biodiversity and its state-of-art where produced by Rocha (2003) for Brazil and by Ismael et al. (1999) for São Paulo State. Based on an assessment of all these publications, it is evident that taxonomy enhancement, distributional patterns, access to informational databases and new technics are important to support the research.

In the early 2000's several scientiometric studies of limnological areas of Brazil were conducted (Thomaz et al., 2010; Melo et al., 2006; Padial et al., 2008; Nabout et al., 2015a), highlighting advances made since the 1970s and ongoing trends. In addition, a scientiometric study focused on climatic change has been recently reported (Nabout et al., 2012), as has a phytoplankton-based study (Carneiro et al., 2008). Marques and Lamas (2006) conducted an important study into the current state of Brazilian zoological taxonomy and highlighted several important local aspects of this science, and Borges et al. (2014) pointed out that one main gap in cerrado biome researches concerns freshwater organisms.

In Brazilian territory, the first studies of microcrustaceans were published at the end of the $19^{\text {th }}$ and the beginning of $20^{\text {th }}$ centuries, initially focusing on taxonomy (Sars, 1901; Van Douve, 1912; Wright, 1936; Kiefer, 1933). After the 1970s, papers addressing the ecology of microcrustaceans began to appear more frequently, starting with São Paulo reservoir research (Matsumura-Tundisi and Tundisi, 1976; Rocha et al., 1982), Rio Doce Valley Lake studies (MatsumuraTundisi \& Okano, 1983; Matsumura-Tundisi et al., 1984) and some Amazonian works (Brandorff, 1978; MatsumuraTundisi et al., 1983); these currently represent the majority of such studies coming out of Brazil (e.g., Landa et al., 2007; Nogueira et al., 2008).

Here we focus our analyses on the principal microcrustacean groups, addressing six key questions: 1) In which federated states are these organisms best studied?; 2) Which environments have been analyzed?; 3) Which are the principal groups of microcrustaceans studied?; 4) How many articles addressing microcrustaceans were produced in each year between 1990 and 2014?; 5) Which are the main lines of study addressing microcrustaceans?; and 6) Which are the publication destinations for Brazilian microcrustacean studies? The data presented here completes a long-standing gap in our knowledge of these organisms in Brazil and has been used to propose the future directions for research in this field within Brazil.

\section{Material and Methods}

Only studies addressing continental waters were included in our analysis (i.e., excluding studies focused on oceans, seas and estuaries due the interference of these kinds of organisms). Book chapters and special volumes were not included. Studies were identified using Google Scholar, ISI Web of Knowledge, Scopus and Scielo. Studies about plankton in general were divided according to crustacean group. The complete list of papers used here are shown in Supplementary file S1. The following keywords were used to search for interesting papers: microcrustaceans, Copepoda, Cyclopoida, Calanoida, Harpacticoida, Ergasilidae, Cladocera, Ostracoda, Conchostraca, zooplankton, reservoir, river, ponds, reservoirs, wetlands, caves, lakes, limnology, ecology, aquatic, taxonomy, systematics, morphology and biogeography. These keywords were searched individually, and in pairs using the plus sign, and "1990-2014". Papers found during this period were separated for analysis.

With the papers, a spreadsheet was divided according to microcrustacean group: Copepoda (sub-divided into Calanoida, Cyclopoida, Harpacticoida and Ergasilidae), Ostracoda and Branchiopoda (sub-divided into Diplostraca (Cladocera), Conchostraca, Notostraca and Anostraca). The Brazilian microcrustacean studies found were divided according to the federative states addressed (27 in total), year of publication (between 1990 and 2014), type of environment (natural lakes, reservoirs for water supply, hydropower generation reservoirs, urban reservoirs, floodplains, rivers, pools, ponds, wetlands, phytothelmata, caves or other) and line of investigation (ecology, biogeography, taxonomy, ecotoxicology, phylogeny, molecular biology or other). For studies developed in more than one federated state, all relevant states were added to the spreadsheet. For studies with overlapping data groups, the category "several" 
was created within each type of environment; for other categories, the study was duplicated within each of the relevant sub-groups. Studies with very specific lines of investigation (e.g., in applied sciences) were included in the "other" category, which was also done for the crustacean groupings. Journals were also ranked according to the number of published articles addressing microcrustaceans and the journal impact factor (according to the ISI) for 2013 was noted. A linear regression analysis was performed between the number of published microcrustacean articles and the impact factors of the destination journals.

\section{Results}

We identified 179 studies addressing selected groups of microcrustaceans, which are listed in a Supplementary file S1. Almost all of the 27 Brazilian federated states (plus one Federal District) (Figure 1A) have produced a microcrustacean study, excepting four: Amapá-AP, Roraima-RR, Alagoas-AL and Espírito-Santo-ES. The most of the studies were published in the states of São Paulo (27\%), Minas Gerais (9\%) and Paraná (8\%).

The most studied environments were hydroelectric reservoirs $(22 \%)$, multiple environments $(22 \%)$, rivers
(14\%) and reservoirs (including artificial small lakes for ornamentation, aquiculture and water supply) (11\%) (Figure 1B). Pools, ponds, small lakes, wetlands and phytothelma were not often studied. Branchiopoda Cladocera (48\%) and Copepoda (48\%) were the most studied groups (Figure 1C). Among the Branchiopoda, no studies addressed the Notostraca, Anostraca or Conchostraca order.

There was an increase in the frequency of microcrustacean studies after 2001 (Figure 1D). Although few microcrustacean studies were published in 2007, 2012 and 2014, these years tended to be followed by years with large numbers of microcrustacean publications.

Ecology was the most common line of investigation, accounting for almost half of the publications, with taxonomy as the next most popular approach (Figure 1E).

Three journals accounted for $44 \%$ ( 77 articles) of the Brazilian microcrustacean publications included in our analyses (Table 1). These were Revista Brasileira de Biologia (Brazilian Journal of Biology), which accounted for $21.8 \%$ of the articles; Hydrobiologia accounting for 13.2\%; and Acta Limnologica Brasiliensia accounting for $9.1 \%$. Other journals, each with fewer than eight articles, accounted for the remaining $56 \%$ of published articles.
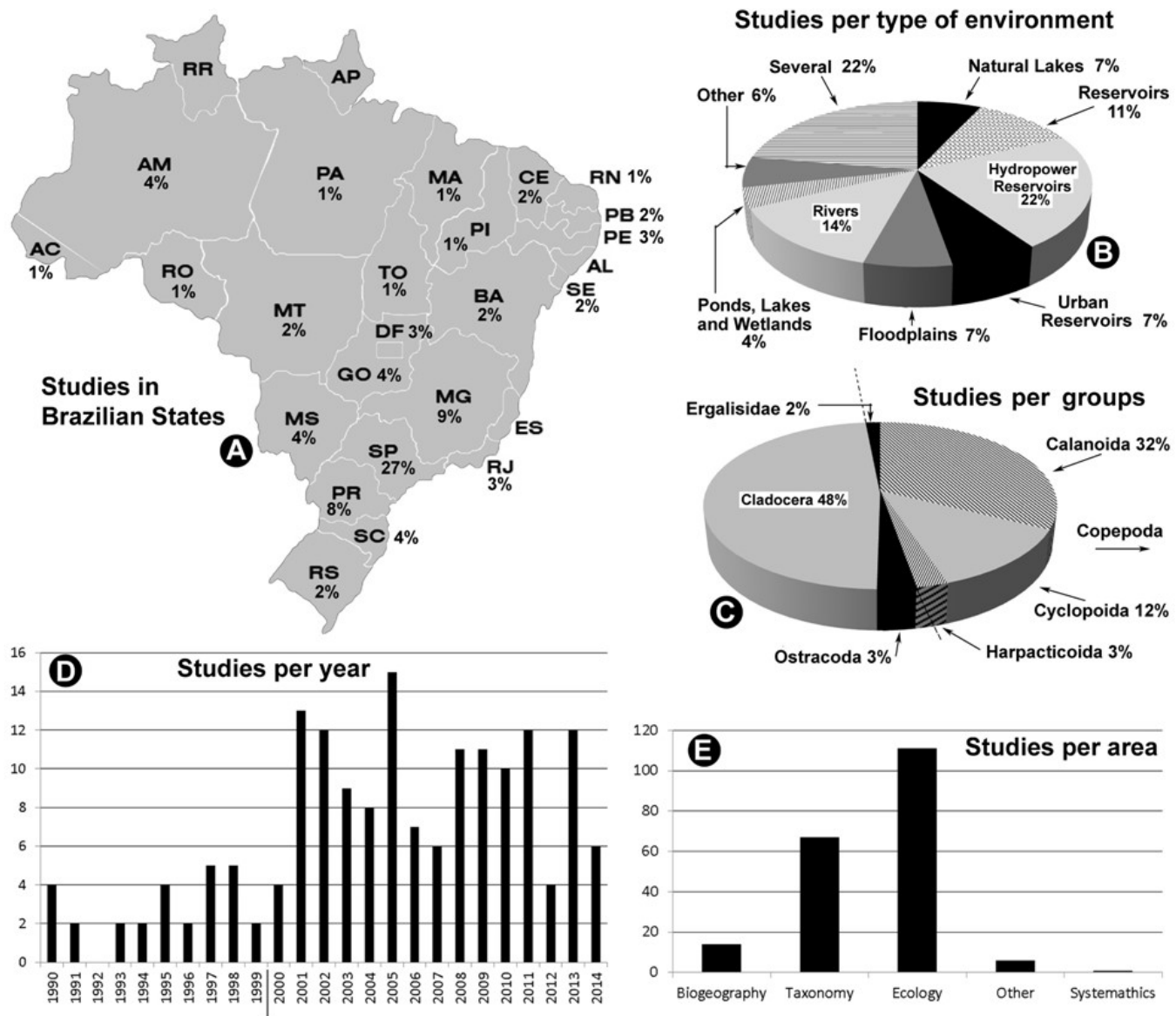

Figure 1. Number of studies about microcrustaceans in Brazilians States (A), in type of environment (B), in higher taxonomic level groups (C), in year between 1990 and 2014 (D), and in study lines area (E). 
Table 1. Total number of studies on microcrustaceans per journal, including Brazilian and international journals. The impact factor (I.F.) was added according to 2013 year.

\begin{tabular}{|c|c|c|c|c|c|}
\hline Journal Name & Total & I.F. & Journal Name & Total & I.F. \\
\hline Brazilian Journal of Biology & 39 & 0.67 & Biological Perspectives & 1 & 0 \\
\hline Hydrobiologia & 23 & 2.21 & Bios & 1 & 0 \\
\hline Acta Limnologica Brasiliensia & 15 & 0.27 & Biotemas & 1 & 0 \\
\hline Nauplius & 7 & 0.21 & $\begin{array}{l}\text { Boletim do Instituto de Pesca de São } \\
\text { Paulo }\end{array}$ & 1 & 0.34 \\
\hline Zootaxa & 8 & 1.06 & $\begin{array}{l}\text { Brazilian Journal of Aquatic Sciences } \\
\text { and Technology }\end{array}$ & 1 & 0 \\
\hline Biota Neotropica & 7 & 0.69 & Crustaceana & 1 & 0.47 \\
\hline Checklist & 6 & 0.3 & Freshwater Biology & 1 & 2.9 \\
\hline Acta Scientarum Biological Sciences & 5 & 0 & Frontiers in Zoology & 1 & 2.3 \\
\hline Iheringia Série Zoologia & 5 & 0.50 & $\begin{array}{l}\text { Interdisciplinary Journal of Applied } \\
\text { Science }\end{array}$ & 1 & 0 \\
\hline Zoologia (Curitiba) & 5 & 0.65 & International Journal of Biodiversity & 1 & 0 \\
\hline Zoological Journal of Linnean Society & 4 & 2.65 & $\begin{array}{l}\text { International Journal of Ecology and } \\
\text { Environmental Sciences }\end{array}$ & 1 & 0 \\
\hline Journal of Plankton Research & 3 & 2.23 & International Journal for Zoology & 1 & 1.94 \\
\hline Revista Landa & 3 & 0 & Journal of Limnology & 1 & 1.08 \\
\hline $\begin{array}{l}\text { Proceedings of the Biological Society of } \\
\text { Washington }\end{array}$ & 3 & 0.56 & Journal of Marine Systems & 1 & 2.48 \\
\hline $\begin{array}{l}\text { Verhandlungen des Internationalen } \\
\text { Verein Limnologie }\end{array}$ & 3 & 0 & Limnetica & 1 & 0.78 \\
\hline $\begin{array}{l}\text { Brazilian Archives of Biology and } \\
\text { Technology }\end{array}$ & 2 & 0.45 & Limnotemas & 1 & 0 \\
\hline International Review of Hydrobiology & 2 & 1.01 & Oecologia Australis & 1 & 0 \\
\hline Journal of Crustacean Biology & 2 & 1.19 & Oecologia & 1 & 3.24 \\
\hline Journal of Natural History & 2 & 0.92 & $\begin{array}{l}\text { Pan American Journal of Aquatic } \\
\text { Sciences }\end{array}$ & 1 & 0 \\
\hline $\begin{array}{l}\text { Lakes and Reservoirs: Research and } \\
\text { Management }\end{array}$ & 2 & 0 & $\begin{array}{l}\text { Studies on NeotropicalFauna and } \\
\text { Environment }\end{array}$ & 1 & 0.56 \\
\hline $\begin{array}{l}\text { Latin American Journal of Aquatic } \\
\text { Sciences }\end{array}$ & 2 & 0.42 & Amazoniana & 1 & 0.23 \\
\hline Limnologica & 2 & 1.66 & Revista Brasileira de Zoociências & 1 & 0 \\
\hline Systematic Parasitology & 2 & 1.04 & PlosOne & 1 & 3.5 \\
\hline
\end{tabular}

No significant linear regression $\left(\mathrm{r}^{2}=0.0034 ; \mathrm{p}=0.7\right)$ was identified between the number of published microcrustacean articles and the journals impact factors (Figure 2).

\section{Discussion}

The data group analyzed in this work comprised an important part of the studies on microcrustaceans in Brazil between 1990-2014 and the general trends observed allow us to propose some important future directions for the field. Thus, this microcrustacean study came to add information to other Brazilian scientiometric studies in limnology (e.g., Thomaz et al., 2010; Melo et al., 2006; Padial et al., 2008; Nabout et al., 2015a) and help to emphasize the gaps and biases for researchers and policy makers.

Regarding the Brazilian regions in which microcrustacean research had been conducted, studies tended to be concentrated around ancient research centers and were related to the number of active scientists, which is in line

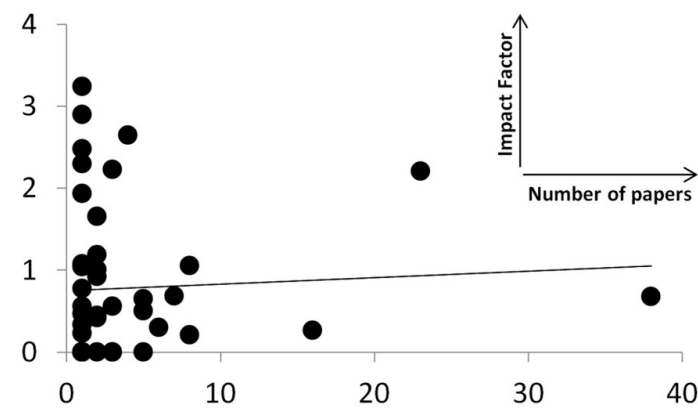

Figure 2. Linear regression between number of papers and impact factor of the journals.

with previous studies (Melo et al., 2006; Abt, 2007). There is a greater number of research centers (and microcrustacean researchers) in the states of São Paulo, Minas Gerais and Paraná, which together accounted for almost half of the 
published studies. This result is similar if we consider the number of limnology articles published in the journal Hydrobiologia by Brazilian researchers (Melo et al., 2006) and also the taxonomy in general (Marques and Lamas, 2006), highlighting the leadership of the State of São Paulo, as determined by the strength of this state's research agency (FAPESP - "Fundação de Amparo a Pesquisa do Estado de São Paulo"). This funding body is one the oldest in Brazil and has a history of supporting special limnological research programs, thus strengthening many research groups and post-graduate programs (Silva, 1996). Moreover, at the beginning of the 2000s, the Biota/FAPESP program supported taxonomy research studies, including many crustacean groups). Borges (2011) and Botelho and Almeida (2012) demonstrated the importance of this state's research agency for science, innovation and technology in Brazil and found that the low publication rate of other Brazilian states is related to the relatively young age of these states' research agencies. São Paulo is the richest state in Brazil and a state law secures $1 \%$ of commercial taxes for this agency (São Paulo, 2014).

A similar number of publications were recorded for the states of Minas Gerais and Paraná, which each host a significant number of researchers specializing in microcrustaceans and limnology. The Research Center for Ichthyology, Limnology and Aquaculture (NUPELIA-UEM) is based in Paraná. NUPELIA-UEM is currently responsible for a large proportion of Brazil's limnological research articles, most of which involve strong international collaborations (Melo et al., 2006).

This current scenario could change in the future because of the emergence and growth of other research centers, fostered by the current expansion in scientific research investments currently underway in Brazil. This is the case for states where emerging centers have been installed in recent years and are very promising such as Rio Grande do Norte with a Post-Graduate Program in Ecology (Chellappa et al., 2013) and Pará, with a Post-Graduate Program in Amazonic Continental Aquatic Resources of the Amazonia.

In contrast, it will be necessary to invest in resources and training for microcrustacean researchers in states with little or no history of such research for inland waters, notably Alagoas, Espírito Santo, Acre, Amapá, Maranhão, Piauí, Rondônia, Roraima and Tocantins, among others. These same states have been highlighted by Marques and Lamas (2006) for the necessity of investment in taxonomy research. Marques and Lamas (2006) also propose the types and amounts of investments needed in Brazilian research.

Reservoirs (artificial lakes) and rivers are the environments in which microcrustaceans have been most studied. For the former, there have been great incentives for studies (especially financial) about hydroelectric reservoirs, as Brazil's energy matrix is over $90 \%$ dependent on dams (Tundisi and Matsumura-Tundisi, 2003). This result also agrees with Melo et al. (2006) on limnological studies in Brazil.
Brazil is rich in river environments, and some of the most important centers for limnological research in the country (e.g., NUPELIA/UEM) have research bases situated on the banks of large rivers (e.g., the Paraná River). This baseline survey enabled the production of several scientific articles in this region, especially in flood plains and also in various types of environments such as reservoirs.

The most studied microcrustacean groups (cladocerans and copepods) were abundant in open water reservoirs and rivers. These organisms have been studied in Brazil since the mid-1900s, as have ostracods. However, there historically have been fewer Brazilian specialists in ostracods than in cladocerans and copepods, indicated by the low number of published articles. For other groups of Branchiopoda (such as Notostraca, Anostraca and Conchostraca), current knowledge is minimal, suggesting an immediate need for specialist training, especially of taxonomists to provide reliable identification bases.

Since 2000 there has been an increase in the frequency of microcrustacean studies. One reason possibly was due to the exponential expansion of the internet after 2000, bringing the global network and ease of access, despite the low Brazilian internet data capacity when compared to high technology countries (Adena, 2014). Another important contribution was the implementation of Scielo (Scientific Electronic Library Online) in 1998, the principal Brazilian free access platform (Meneghini et al., 2006). Marques and Lamas (2006) mention the "spontaneous action" and "induced action" of the Brazilian government in research after 1990, which certainly contributed to the development of several areas of study in this country. It is important to emphasize that $30 \%$ of the resources for scientific research in Brazil since 2003 have been destined for particular geopolitical areas, as the North, Northeast and Center-West.

Ecology was identified as the most common line of investigation, reflecting the intensive efforts that have been made in this area since the 1980s. This was essentially the result of all the newly established researchers having been taught by only a few core professors or researchers, for example, in the state of São Paulo (e.g., Professor José Galizia Tundisi of the University of São Paulo and the Federal University of São Carlos (UFSCar). After the 1980s, centers of excellence in ecology and limnology were formed (Silva, 1996), resulting in greater representation of the area in the study of microcrustaceans. In 1997, the Brazilian government implemented the Long-Term Ecological Research Network Program (PELD in Portuguese), contributing directly to the growth of ecologists, and in the states of Amazonas, São Paulo, Minas Gerais and Paraná, aquatic ecology has a strong influence.

Taxonomy was very well represented especially in the early 1900 s, when virtually all the microcrustacean fauna were described, especially by foreign researchers visiting Brazil on expeditions (Kiefer, 1933; Wright, 1936). However, we found that taxonomy was decreasing in the number of studies after 1990, which is in line with a general declining trend in taxonomy (Marques and Lamas, 
2006). Not many new species have been described recently, probably due to the combination of few taxonomists and an absence of sampling in some states of northern Brazil. This absence can be attributed to the large land area and the concentration of studies around a few locations (Perbiche-Neves et al., 2014), and to a majority of the sampled environments being rivers and reservoirs, although many new species are expected in different environments (e.g., caves, humid rocks).

The taxonomic resolution of species within various microcrustacean groups is another long-running goal for taxonomists, which, together with systematists, should also prepare for the various major phylogenetic groups. The systematic and phylogeny, though old, have been neglected by Brazilian students. Molecular techniques have contributed to the development of complex phylogenies with many taxonomic groups; however, phylogenies using traditional morphological data appear to have been neglected. Although there are examples of some studies that combine molecular and morphological approaches (Wyngaard et al., 2010), this is rare within Brazil. While such a combination approach is likely to become increasingly popular in Brazil, more time is required to obtain and analyze the data. Other lines of investigation (e.g., biogeography and molecular biology) have been widely applied and may be considered emerging research fields.

Acta Limnologica Brasiliensia was the most popular publication destination for microcrustacean research articles. The large number of publications can be accounted for by the long-standing tradition of zooplankton studies in Brazil. This journal publishes many kind of studies, including descriptive manuscripts. The high number of publications in Hydrobiologia maintains a tradition of limnological publications in this journal (Melo et al., 2006), possibly associated with such advantages as special and normal numerous volumes each year, wide comprehensiveness of areas, generally fast review, and the sheer number of volumes per year. Sharing similar features is the Brazilian Journal of Biology, which has a general scope across biology and publishes many volumes.

Few ecology papers on microcrustaceans from Brazil have been published in other relevant journals (e.g., Freshwater Biology, Oikos and Ecology). One possible explanation for this is that these journals are reluctant to include regional or local studies, unlike the other journals cited previously. Also, the lack of a strong theoretical basis and concepts relevant to the computational and numerical tools used by modern ecological studies might prejudice the acceptance of such articles. Similarly, few taxonomy studies have been published in important journals, such as Zootaxa, Biological Journal of Linnaean Society, Journal of Natural History and Zookeys. Few papers well-grounded in revision or new species descriptions have been produced, which have been distributed among several prestigious journals, including those mentioned above. However, many of these journals charge expensive publication rates for Brazilians and the post-graduate policy for publishing is irregular.
There was no significant correlation between the number of published microcrustacean articles and the impact factor of the destination journal. This result suggests that we have not had an increase in the quality (impact factor) of publications according to the number of accepted papers; it is possible that this scenario will change in the long term. The main reason may be related to the preference by Brazilian microcrustacean researchers to publish in more traditional journals for limnology and crustacean areas in contrast, for example, with few researches concentering many works with metacommunities, which were published in journals with a high-impact factor.

The study of microcrustaceans in Brazil is more associated with limnology than with carcinology, as shown by the relative number of studies addressing these organisms in the beginning 2010's Brazilian scientific meetings. We propose that it would be useful to create a new specific event for microcrustacean groups in Brazil (within other conferences, for example), with the aim of bringing together researchers that currently attend different events.

Finally, we propose some future topics and goals for microcrustacean studies in Brazil. Production of keys and guides for the correct identification of species will be critical. Connected to this, there is an urgent need to expand the training of taxonomists; it will first be necessary to establish the existing fauna in the country focusing especially in descriptive papers. Studies involving multiple states, environments and taxonomic groups had considerable importance among the papers produced, and this combination has proved beneficial to knowledge of these organisms and biodiversity in general. We must also invest in emerging fields, such as molecular biology with systematics, aiming to reveal the historical processes affecting microcrustacean life. In the field of ecology, futures studies require a strong theoretical basis and experimental design, and should be written for a wide range of readers (rather than as local studies, as have been produced in Brazil in recent decades). We suggest conducting studies in the states mentioned above for which there are currently few available articles and to address phytothelmatas environments, caves, pools of water, mountains, hygropetric, mosses, and other less commonly studied environments. The trend for publishing within three particular journals is likely to be maintained for years to come, given their wide acceptance and dissemination. Another important trend identified here is the disappearance of roles - single author, as mentioned by Nabout et al. (2015b). Another is the emergence of publication in open access journals with data investigations that form in a robust and reliable database as Scielo. These are a key to increasing scientific dissemination (Lawrence and Giles, 1999; Lawrence et al, 2001).

\section{Acknowledgements}

We thank to anonymous reviewer for suggestion and remarks for improve the quality of this manuscript. 


\section{References}

ABT, H.A., 2007. The publication rate of scientific papers depends only on the number of scientists. Scientometrics, vol. 73, no. 3, pp. 281-288. http://dx.doi.org/10.1007/s11192-007-1807-8.

ADENA, S.R., 2014. Why Brazil is not ready for the Twenty-First Century Taxonomy: a zoological view. Sitientibus série Ciências Biológicas, vol. 13, p. 1-7. http://dx.doi.org/10.13102/scb201.

BORGES, M.N., 2011. As fundações estaduais de amparo à pesquisa e o desenvolvimento da ciência, tecnologia e inovação no Brasil. Revista USP, vol. 89, no. 89, pp. 174-189. http://dx.doi. org/10.11606/issn.2316-9036.v0i89p174-189.

BORGES, P.P., OLIVEIRA, K.A.F.D.A., MACHADO, K.B., VAZ, Ú.L., CUNHA, H.F. and NABOUT, J.C., 2014. Trends and gaps of the scientific literature on the Cerrado biome: A scientometric analysis. Neotropical Biology and Conservation, vol. 10, pp. 2-8.

BOTELHO, A. and ALMEIDA, N., 2012. Desconstruindo a política científica no Brasil: evolução da descentralização da política de apoio à pesquisa e inovação. Revista Sociedade e Estado, vol. 27, no. 1, pp. 117-132. http://dx.doi.org/10.1590/ S0102-69922012000100008.

BOXSHALL, G.A. and DEFAYE, D., 2008. Global diversity of copepods (Crustacea: Copepoda) in freshwater. Hydrobiologia, vol. 595, no. 1, pp. 195-207. http://dx.doi.org/10.1007/s10750007-9014-4.

BRANDORFF, G.O., 1978. Preliminare comparision of the crustacean plankton of a white water and blak lake in central Amazonia. Verhandlungen des Internationalen Verein Limnologie., vol. 20, pp. 1198-1202.

BRENDONCK, L., ROGERS, D.C., OLESEN, J., WEEKS, S. and HOEH, W.R., 2008. Global diversity of large branchiopods (Crustacea: Branchiopoda) in freshwater. Hydrobiologia, vol. 595, no. 1, pp. 167-176. http://dx.doi.org/10.1007/s10750-007-9119-9.

CARNEIRO, F.M., NABOUT, J.C. and BINI, L.M., 2008. Trends in the scientific literature on phytoplankton. Limnology, vol. 9, no. 2, pp. 153-158. http://dx.doi.org/10.1007/s10201-008-0242-8.

CHELLAPPA, S., MARINHO-SORIANO, E. and CÂMARA, M.R. and AMADO, A.M., 2013. Ciências Aquáticas: 50 anos de pesquisa no Rio Grande do Norte, Brasil. Natal: Editora ServiGraf, 2013, vol. 1. 208 p.

FORRÓ, L., KOROVCHINSKY, N.M., KOTOV, A.A. and PETRUSEK, A., 2008. Global diversity of cladocerans (Cladocera; Crustacea) in freshwater. Hydrobiologia, vol. 595, no. 1, pp. 177184. http://dx.doi.org/10.1007/s10750-007-9013-5.

ISMAEL, D.; VALENTI, V.C.; MATSUMURA-TUNDISI, T. and ROCHA, O., 1999. Biodiversidade do Estado de São Paulo, Brasil - Invertebrados de Água Doce. São Paulo: FAPESP, vol. 4. 176 p.

KIEFER, F., 1933. Süßwassercopepoden aus Brasilien. Zoologischer Anzeiger, vol. 105, pp. 38-43.

LANDA, G.G., BARBOSA, F.A.R., RIETZLER, A.C. and BARBOSA, P.M., 2007. Thermocyclops decipiens (Kiefer, 1929) (Copepoda, Cyclopoida) as Indicator of Water Quality in the State of Minas Gerais, Brazil. Brazilian Archives of Biology and Technology, vol. 50, no. 4, pp. 695-705. http://dx.doi.org/10.1590/ S1516-89132007000400015.

LAWRENCE, S. and GILES, C.L., 1999. Searching the Web: General and scientific information access. IEEE Comm., vol. 37, no. 1, pp. 116-122. http://dx.doi.org/10.1109/35.739314.
LAWRENCE, S., PENNOCK, D.M., FLAKE, G.W., KROVETZ, R., COETZEE, F.M., GLOVER, E., NIELSEN, F.A., KRUGER, A. and GILES, C.L., 2001. Persistence of Web References in Scientific Research. Computer, vol. 34, no. 2, pp. 26-31. http:// dx.doi.org/10.1109/2.901164.

MARQUES, A.C. and LAMAS, C.J.E., 2006. Taxonomia zoológica no Brasil: estado da arte, expectativas e sugestões de ações futuras. Papéis Avulsos de Zoologia, vol. 46, no. 13, pp. 139-174.

MARTENS, K., SCHON, I., MEISCH, C. and HORNE, D.J., 2008. Global diversity of ostracods (Ostracoda, Crustacea) in freshwater. Hydrobiologia, vol. 595, no. 1, pp. 185-193. http:// dx.doi.org/10.1007/s10750-007-9245-4.

MATSUMURA-TUNDISI, T. and OKANO, W., 1983. Seasonal fluctuiations of Copepod populations in Lake Dom Helvécio (Parque Florestal, Rio Doce, Minas Gerais, Brazil). Revue d'Hydrobiologie Tropicale, vol. 16, no. 1, pp. 35-39.

MATSUMURA-TUNDISI, T. and TUNDISI, J.G., 1976. Plankton studies in a lacustrine environment, I. Preliminary data on zooplankton ecology on Broa Reservoir. Oecologia, vol. 25, no. 3, pp. 265-270. http://dx.doi.org/10.1007/BF00345103.

MATSUMURA-TUNDISI, T., ROCHA, O. and HARDY, E.R., 1983. On the mechanism for the coexistence species of zooplankton in Amazonian lakes. Tropical Ecology, vol. 24, no. 1, pp. 44-48.

MATSUMURA-TUNDISI, T., TUNDISI, J.G. and TAVARES, L.S., 1984. Diel migration and vertical distribution of Cladocera in Lake D. Helvecio (Minas Gerais, Brazil). Hydrobiologia, vol. 113, no. 1, pp. 299-306. http://dx.doi.org/10.1007/BF00026616.

MELO, A.S., BINI, L.M. and CARVALHO, P., 2006. Brazilian articles in international journals on Limnology. Scientometrics, vol. 67, no. 2, pp. 187-199. http://dx.doi.org/10.1007/s11192006-0093-1.

MENEGHINI, R., MUGNAINI, R. and PACKER, A.L., 2006. International versus national oriented Brazilian scientific journals. A scientometric analysis based on SciELO and JCR-ISI databases. Scientometrics, vol. 69, no. 3, pp. 529-538. http://dx.doi.org/10.1007/ s11192-006-0168-z.

NABOUT, J.C., CARNEIRO, F.M., BORGES, P.P., MACHADO, K.B. and HUSZAR, V.L.M., 2015a. Brazilian scientific production on phytoplankton studies: national determinants and international comparisons. Brazilian Journal of Biology $=$ Revista Brasileira de Biologia, vol. 75, no. 1, pp. 216-223. PMid:25945640. http:// dx.doi.org/10.1590/1519-6984.11713.

NABOUT, J.C., CARVALHO, P., PRADO, M.U., BORGES, P.P., MACHADO, K.B., HADDAD, K.B., MICHELAN, T.S., CUNHA, H.F. and SOARES, T.N., 2012. Trends and biases in global climate change literature. Natureza \& Conservação, vol. 10, no. 1, pp. 45-51. http://dx.doi.org/10.4322/natcon.2012.008.

NABOUT, J.C., PARREIRA, M.R., TERESA, F.B., CARNEIRO, F.M., CUNHA, H.F., ONDEI, L.S., CARAMORI, S.S. and SOARES, T.N., 2015b. Publish (in a group) or perish (alone): the trend from single- to multi-authorship in biological papers. Scientometrics, vol. 102 , no. 1, pp. 357-364. http://dx.doi. org/10.1007/s11192-014-1385-5.

NOGUEIRA, M.G., REIS-OLIVEIRA, P.C. and BRITTO, Y.T., 2008. Zooplankton assemblages (Copepoda and Cladocera) in a cascade of reservoirs of a large tropical river (SE Brazil). Limnetica, vol. 27, no. 1, pp. 151-170.

PADIAL, A.A., BINI, L.M. and THOMAZ, S.M., 2008. The study of aquatic macrophytes in neotropics: a scientometrical 
view of the main trends and gaps. Brazilian Journal of Biology = Revista Brasileira de Biologia, vol. 68, no. 4, (suppl.), pp. 139-147. PMid:19197475. http://dx.doi.org/10.1590/S151969842008000500012 .

PERBICHE-NEVES, G., PREVIATTELLI, D., PIE, M.R., DURAN, A., SUÁREZ-MORALES, E., BOXSHALL, G.A., NOGUEIRA, M.G. and ROCHA, C.E.F., 2014. Historical biogeography of the neotropical Diaptomidae (Crustacea: Copepoda). Frontiers in Zoology, vol. 11, no. 1, pp. 36. PMid:25057279. http://dx.doi. org/10.1186/1742-9994-11-36.

ROCHA, O., 2003. Águas Doces: avaliação do estado do conhecimento da diversidade biológica do Brasil. Brasília: Ministério do Meio Ambiente. 70 p. Projeto Estratégia Nacional de Diversidade Biológica (Bra 97 G 31).

ROCHA, O., MATSUMURA-TUNDISI, T. and TUNDISI, J.G., 1982. Seasonal fluctuation of Argyrodiaptomus furcatus population in the Lobo Reservoir (São Carlos, SP, Brazil). Tropical Ecology, vol. 23 , no. 16 , pp. 134-150.

SÃO PAULO, 2014 [viewed 1 January 2014]. Legislação do Estado de São Paulo [online]. São Paulo: Governo do Estado de São Paulo. Available from: http://www.legislacao.sp.gov.br/ legislacao/index.htm

SARS, G.O., 1901. Contribution to the knowledge of the freshwater Entomostraca of South America. Part I. Cladocera. Archiv für Mathematik og Naturvidenskab. Christiana, vol. 23, no. 3, pp. 1-102.

SILVA, C.A., 1996. Contribuição da FAPESP à ciência e tecnologia. Estudos Avançados, vol. 10, no. 28, pp. 211-227. http://dx.doi. org/10.1590/S0103-40141996000300009.
THOMAZ, S.M., MICHELAN, T.S., CARVALHO, P. and BINI, L.M., 2010. The influence of "Homage to Santa Rosalia" on aquatic ecology: a scientometric approach. Hydrobiologia, vol. 653, no. 1, pp. 7-132. http://dx.doi.org/10.1007/s10750-010-0342-4.

THORP, J.H. and COVICH, A.P., 2001. Ecology and classification of North American freshwater invertebrates. 2nd ed. San Diego: Academic Press. 1056 p.

TUNDISI, J.G. and MATSUMURA-TUNDISI, T., 2003. Integration of research and management in optimizing multiple uses of reservoirs: the experience in South America and Brazilian case studies. Hydrobiologia, vol. 500, no. 1-3, pp. 231-242. http:// dx.doi.org/10.1023/A:1024617102056.

VADADI-FÜLÖP, C., SIPKAY, C., MÉSZÁROS, G. and HUFNAGEL, L., 2012. Climate change and freshwater zooplankton: what does it boil down to? Aquatic Ecology, vol. 46, no. 4, pp. 501-519. http://dx.doi.org/10.1007/s10452-012-9418-8.

VAN DOUVE, V.C., 1912. Zur Kenntnis der Süsswassercopepoden von Brasilien. Sonderahdruck aus dem Archiv für Hydrobiologie und Planktonkunde, vol. 7, no. 2, pp. 309-321.

WRIGHT, S., 1936. Preliminary report on six new species of Diaptomus from Brazil. Anais da Annales da Academia Brasileira de Sciencias, vol. 8, no. 2, pp. 79-85.

WYNGAARD, G.A., HOLYNSKA, M. and SCHULTE 2nd., J.A., 2010. Phylogeny of the freshwater copepod Mesocyclops (Crustacea: Cyclopoida) based on combined molecular and morphological data, with notes on biogeography. Molecular Phylogenetics and Evolution, vol. 55, no. 3, pp. 753-764. PMid:20197098. http:// dx.doi.org/10.1016/j.ympev.2010.02.029. 